(1)

\title{
Hype, disillusionment and capacity problems: Turkish Cypriot media and the European Union
}

\section{loannis N. Grigoriadis \& Cagkan Felek}

To cite this article: Ioannis N. Grigoriadis \& Cagkan Felek (2019) Hype, disillusionment and capacity problems: Turkish Cypriot media and the European Union, Middle Eastern Studies, 55:1, 111-126, DOI: $10.1080 / 00263206.2018 .1504779$

To link to this article: https://doi.org/10.1080/00263206.2018.1504779

\section{曲 Published online: 02 Nov 2018.}

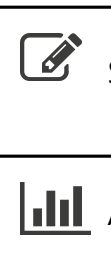

Submit your article to this journal $๘$

III Article views: 36

View Crossmark data ¿ 


\title{
Hype, disillusionment and capacity problems: Turkish Cypriot media and the European Union
}

\author{
loannis N. Grigoriadis (D) and Cagkan Felek (D) \\ Department of Political Science \& Public Administration, Bilkent University, Ankara, Turkey
}

The persistence of the Cyprus problem has historically complicated relations between the European Union (EU) and the Turkish Cypriot community. Legal barriers due to the internationally non-recognised status of the 'Turkish Republic of Northern Cyprus (TRNC)' and weak engagement of Turkish Cypriot administrative bodies have led the EU to seek collaboration through sub-state actors. Turkish Cypriot political parties, chambers of commerce and industry, labour unions and various non-governmental organisations acquired a disproportionate influence as far as the course of EU-Turkish Cypriot relations and the Europeanisation process in the northern part of Cyprus were concerned. In particular, the role of the local media ${ }^{1}$ in the Europeanisation process in the northern part of Cyprus and the relationship between Turkish Cypriot community and the EU has remained under-researched.

This article explores the role of local media in shaping perceptions of the Turkish Cypriot community towards the EU, as well as the Turkish Cypriot public sphere regarding EU matters. Previous studies contributed to the literature on the relationship between the Turkish Cypriot community and the EU by analysing the role of sub-state institutions as mediating factors influencing the direction, speed and progress of the Europeanisation process, by using the 'contested statehood' conceptual framework. Those studies considered the 'TRNC' as a contested state whose independence was unilaterally declared in 1983, but which could not gain international diplomatic recognition. ${ }^{2}$ Hence, they focused on the developing relationship between Turkish Cypriot administrative bodies, political parties, civil society organisations and the EU institutions in particular in the post-Annan Plan $^{3}$ Referendum period. ${ }^{4}$ In addition to these, local media have played an important role in contributing to the Europeanisation process of the Turkish Cypriot community and setting the agenda of EU-related affairs. The media remain crucial in shaping the national public attitudes towards the EU and influencing the social and political change in societies through processes of Europeanisation. ${ }^{5}$

This article aims to fill the existing gap in the literature by exploring the influence of Turkish Cypriot media on the Europeanisation process in the northern part of Cyprus. Recognising the scarcity of sources about the topic, it draws on semi-structured interviews with representatives from Turkish Cypriot media organisations and associations in which Turkish Cypriot journalists are organised. Interviews help to explain how the Turkish Cypriot media regard their role in shaping the local public sphere in the post-2004 period and to identify the patterns of their institutional relationship with the EU. This article relies on Turkish Cypriot newspaper articles, official EU documents and statements and Eurobarometer survey results. Its contribution to the literature is twofold. First, it aims to improve the understanding of the influence of media on the Europeanisation of national public spheres. As the 'democratic deficit' problem is still relevant and forms one of 
the core issues in EU politics, the media ought to function as an institution which empowers the development of Europeanised national public spheres and strengthens that link at the national and supranational levels between the European demos and the EU. Hence, this article adds to the debates on Europeanisation attached to the role of the media and on-going discussions among the European political elite and scholars about solving the 'democratic deficit' problem of the EU. Second, the northern part of Cyprus has experienced an intrinsic type of Europeanisation. Rather than analysing that process with the concept of 'contested statehood', ${ }^{6}$ it is important to emphasise that unlike other 'contested states', Turkish Cypriots have individually gained EU citizenship following the 2004 EU membership of the Republic of Cyprus, even though implementation of the EU legislation is suspended in the northern part of Cyprus. ${ }^{7}$ The situation of other contested states $^{8}$ differs from that of the northern part of Cyprus. Whereas Kosovo, defined as a contested and candidate state for EU membership, is in the process of dialogue with EU institutions for visafree access to the Schengen Area to be provided to Kosovan citizens, ${ }^{9}$ most Turkish Cypriots are not subject to any limitations and benefit from EU rights and freedoms due to their Cypriot citizenship. On the other hand, Palestine, which is defined as another contested state, has engaged in negotiations with EU institutions and member states about having its statehood recognised. ${ }^{10}$ Considering the situation in the northern part of Cyprus, a relationship with the EU is not pursued at the state level, and 'TRNC' institutions have limited involvement in a dialogue with EU institutions. This relationship has been well established at the individual and societal levels. None of the comparisons made between other examples of contested states and the 'TRNC' fully applies to explain the relationship between the Turkish Cypriot community and the EU. Therefore, this article helps improve understanding of the sui generis relationship established between the Turkish Cypriot community and the EU by focusing on the role of the Turkish Cypriot media through horizontal and vertical processes of Europeanisation.

This article is structured as follows. First, it embarks on a brief account of the Cyprus problem. Second, it provides a brief history of Turkish Cypriot media. Then, it explores the ways media influence the national public spheres in the EU with the help of the tools of horizontal and vertical Europeanisation. Finally, the influence of the Turkish Cypriot media in shaping local public opinion towards the EU in the post-Annan Plan period is examined. This study reveals that the role of the Turkish Cypriot media in shaping the local public sphere towards the EU has always been shaped in parallel with developments in the Cyprus peace negotiations. Because the relationship between the Turkish Cypriot community and the EU has improved since 2004, the role of the Turkish Cypriot media in shaping local public opinion towards the EU has also been affected. However, weak institutionalisation of the Turkish Cypriot media has been a negative influence in terms of Europeanisation. It has limited its capacity to further contribute to the improvement of the sui generis relationship between the Turkish Cypriot community and the EU.

\section{The Cyprus problem: an overview}

The Republic of Cyprus was established in 1960 as a bicommunal unitary state. Greek Cypriots comprised approximately 81.5 per cent and Turkish Cypriots approximately 18.5 per cent of the population. ${ }^{11}$ Bicommunal cooperation lasted, however, for only three years. In December 1963, following Greek Cypriot proposals to amend the constitution and the outbreak of intercommunal conflict, Turkish Cypriots withdrew from their participation in state positions. ${ }^{12}$ In light of mounting intercommunal violence, most of them were eventually forced to live in enclaves. Despite domestic turmoil and the collapse of the power-sharing agreement, the Republic of Cyprus maintained its international legal personality but the de facto partition of the two communities introduced by intercommunal conflict became consolidated in July-August 1974, when a Greek Cypriot coup instigated by the Greek Junta aiming to annex Cyprus to Greece was 
followed by Turkey's military operation leading to the de facto division of the island into a Turkish Cypriot north and a Greek Cypriot south.

Conflict resolution efforts failed to deliver a positive result, and nine years later, on 15 November 1983, the independence of the 'Turkish Republic of Northern Cyprus (TRNC)' was declared but received no recognition by the international community except Turkey. Since its establishment, state institutions in the northern part of Cyprus have been deprived of any international status or formal relations. While the sovereignty of the Republic of Cyprus throughout the island has been internationally recognised, United Nations (UN) efforts have focused on lifting the division and achieving the resolution of the conflict through the introduction of a bizonal, bicommunal federal system in line with the bicommunal agreements made since the late 1970s.

Parallel to the developments to find a comprehensive solution to the Cyprus problem, Cyprus's first steps to sign an association agreement with the European Economic Community date back to the 1970s. ${ }^{13}$ Yet, its membership of the Unaligned Movement and the wish to remain neutral in the East-West conflict and avoid antagonising the Soviet Union meant that an application for full membership would only materialise after the Cold War ended in 1990. Accession talks between Cyprus and the EU started in 1998, despite the persistence of the Cyprus dispute. ${ }^{14}$ While EU member states did not want to inherit the Cyprus problem within the EU, it was believed that Cyprus's membership process could have a catalytic impact on the conflict resolution process. ${ }^{15}$ In the December 2002 Copenhagen EU Summit, the Republic of Cyprus was admitted as a new member state of the EU, together with nine other prospective EU members from Central, Eastern Europe and the Mediterranean. Hence, the conflict resolution and membership processes were decoupled. ${ }^{16}$ On 24 April 2004, Greek Cypriots rejected by 75.8 per cent the UN-sponsored Annan Plan whereas 64.9 per cent of the Turkish Cypriots accepted. ${ }^{17} \mathrm{~A}$ week later, on 1 May 2004, Cyprus became an EU member without a peace deal. The whole island was recognised as EU territory, and all Cypriots were recognised as EU citizens. On the other hand, the implementation of EU legislation was suspended in the northern part because the Republic of Cyprus does not exercise official government control over that territory. ${ }^{18}$

The failure to achieve conflict resolution in Cyprus before membership due to the negative vote of Greek Cypriots, led to increased interest by EU officials in mitigating the isolation which Turkish Cypriots had endured in the aftermath of the Annan Plan referendums. In that view, the constructive stance of the Turkish Cypriot community in the Annan Plan referendum should be recognised and rewarded. Among the declarations by international organisations expressing disappointment due to the rejection of the Annan Plan, the European Commission stated:

The European Commission deeply regrets that the Greek Cypriot community did not approve the comprehensive settlement of the Cyprus problem, but it respects the democratic decision of the people. A unique opportunity to bring about a solution to the long-lasting Cyprus issue has been missed. The Commission would like to warmly congratulate Turkish Cypriots for their 'yes' vote. This signals a clear desire of the community to resolve the island's problem. The Commission is ready to consider ways of further promoting economic development of the northern part of Cyprus. The Commission will start its internal reflection on the new situation and will present its views to the Council of Ministers meeting to be held in Luxembourg next Monday. We wish to thank the United Nations Secretary General and his Good Offices team who have worked so hard for a comprehensive solution and for their close cooperation with the European Commission in drawing up their Plan. ${ }^{19}$

Two days later, the Council of the EU stated:

The Turkish Cypriot community have expressed their clear desire for a future within the EU [by voting for the Annan Plan]. The Council is determined to put an end to the isolation of the Turkish Cypriot community and to facilitate the reunification of Cyprus by encouraging the economic development of the Turkish Cypriot community. The Council invited the Commission to bring forward comprehensive proposals to this end with emphasis on the economic integration of the island and on improving contact between the two communities and with the EU. ${ }^{20}$

It was hoped that the increased interest of the EU in the Turkish Cypriot community would lead to more cooperation and interaction through the introduction of new legal instruments. On the 
other hand, the EU membership of the Republic of Cyprus and the persistence of the Cyprus conflict meant that dialogue between the EU and the Turkish Cypriot community would be limited.

\section{Turkish Cypriot media: the historical backdrop}

Turkish Cypriot media trace their roots to the initial phases of British rule in Cyprus, which commenced in 1878. The first printing house in Cyprus, Henry King and Co., was established in 1878 and Kypros/Cyprus was the first newspaper printed in the same year, in Greek and English. ${ }^{21}$ The first newspaper in Ottoman Turkish, Ümid, began to be printed monthly in 1879 by the Armenian intellectual Alexan Sarafian. ${ }^{22}$ Ümid only survived for four months, as it was banned by the British administration because of criticizing the Ottoman administration for transferring the island to British rule. ${ }^{23}$ The first newspaper printed by a Turkish Cypriot intellectual, Ahmet Emin Efendi, was Saded in $1889 .^{24}$ This was followed by Zaman, printed by a group of Turkish Cypriots $^{25}$ organised in a political association named as Osmanlı Kıraathanesi. At the same time, Zaman was the first newspaper weekly printed in a printing house owned by Turkish Cypriots. ${ }^{26}$ Between 1878 and 1918, there were 24 newspapers printed in Ottoman Turkish, and most of these newspapers oriented their publication policies towards emphasising that Cyprus was a Turkish land, rejecting unification of the island with Greece (Enosis) and supporting the Turkish 'national struggle' (milli mücadele) undertaken in Anatolia during the 1919-1922 Greco-Turkish War. ${ }^{27}$

The end of the war not only marked the establishment of the Republic of Turkey on 29 October 1923 but also closely affected the daily lives of Turkish Cypriots. In that regard, the Turkish Cypriot press played a key role in influencing the Turkish Cypriot community to accept and acknowledge the principles and reforms in pursuit of modernisation and Westernisation, which were put forward by Kemal Atatürk following the establishment of the Republic of Turkey. ${ }^{28}$ In 1930 the Turkish Cypriot press, following developments in republican Turkey, adopted the Turkish Latin alphabet. ${ }^{29}$ Until the 1950s, the Turkish Cypriot press largely referred to political developments during the British rule. Newspaper content consisted of explaining political developments in Cyprus, criticising political, social and economic pressures placed on the Turkish Cypriot community by the British administration, keeping Turkish 'national consciousness' alive and helping to increase the literacy rate in the Turkish Cypriot Community by encouraging the use of the Turkish Latin Alphabet. However, the 'Law on Newspapers, Books and Printing Houses' (Gazete, Kitap ve Basımevleri Kanunu), which was enacted by the British Administration, imposed sanctions and pressure on the Turkish Cypriot press, and this led to imprisonment of some journalists and political activists because of their critical views on political developments in Cyprus. $^{30}$ Despite the pressures on the Turkish Cypriot press applied by the British Administration in that period, in 1942, the Halkın Sesi (Voice of the People) ${ }^{31}$ newspaper was published by Fazıl Küçük ${ }^{32}$ and has continued its life until today. In 1960 when the Republic of Cyprus was established, apart from the newspapers, the only state-owned media corporation on the island was the Cyprus Broadcasting Corporation (Radiofoniko Idryma Kyprou-Kıbrı Yayın Kurumu). The personnel of the Cyprus Broadcasting Corporation comprised 70 per cent Greek Cypriots and 30 per cent Turkish Cypriots, but Turkish Cypriot personnel withdrew from their positions as soon as the intercommunal conflict began in $1963 .{ }^{33}$

The period between 1963 and 1974, that is the outbreak of intercommunal conflict and the Turkish military operation, marked a transformation of the strategies of the Turkish Cypriot press, due to mounting intercommunal tension and violence on the island. Newspapers were printed under the impact of the Cyprus question. At that time, the news coverage and editorial policies of Turkish Cypriot newspapers mostly aimed to increase the spirit of the Turkish Cypriot 'national struggle' given in opposition to unification of the island to Greece (Enosis). ${ }^{34}$ The names of the newspapers printed at that period were also chosen in parallel with the changing circumstances 
of the intercommunal conflict with the aim of increasing positive feelings about the Turkish Cypriot 'national struggle', such as Zafer (Victory), Savaş (War) and Mücahit (Fighter). ${ }^{35}$ The first Turkish Cypriot radio channel was established in 1964, at the peak of intercommunal conflict, after Turkish Cypriot personnel withdrew from their positions with the Cyprus Broadcasting Corporation. Called Radio Bayrak, its motto was 'broadcasting the voice of Turkish Cypriots to the world' (Kıbrıs Türkü'nün sesini dünyaya duyurmak). ${ }^{36}$ In 1973, the first news agency, Turkish News Agency-Cyprus (Türk Ajansı-Kıbrıs), was founded. ${ }^{37}$ The establishment of the first television channel, Bayrak TV, followed in $1976 . .^{38}$ During these years, the content of the Turkish Cypriot media was dominated by the Cyprus conflict and bicommunal tension. Publication and broadcasting policies were adopted in parallel to political developments on the island and were used as an instrument to inform people about conflict incidents in different island regions and to organise people to actively participate in the 'national struggle'.

The emergence of Turkish Cypriot political parties in the late 1970s and the establishment of the 'TRNC' in 1983 opened a path to the publication of additional newspapers which were outlets of those political parties' executive organs or were printed by their supporters. Publication and broadcasting policies of the Turkish Cypriot media were also changed, and political attempts to find a comprehensive solution to the Cyprus problem became a priority. ${ }^{39}$ In the 1990 s, Turkish Cypriot media increased in number with improved printing and broadcasting techniques. $^{40}$ In the early 2000s, online media began to emerge. Today, the Turkish Cypriot public sphere is enriched by various media outlets. In addition to the state-owned television and radio channels and a news agency, existence of different privately-owned television and radio channels, online news portals and newspapers provide information to the Turkish Cypriot community. In spring 2018 there were eight television channels, ${ }^{41}$ sixteen radio channels, ${ }^{42}$ nineteen daily newspapers, ${ }^{43}$ nine online news portals, ${ }^{44}$ operating in the northern part of Cyprus. Journalists and workers in the Turkish Cypriot media have also organised themselves into various trade unions and associations. ${ }^{45}$

The Turkish Cypriot media played a significant role in the transformation of Turkish Cypriot politics at the beginning of the 2000s. In 1999-2000, the Turkish economic crisis had a major spill-over effect on the Turkish Cypriot economy leading to a major local banking crisis. ${ }^{46}$ Worsening economic conditions urged civil society organisations and the opposition political parties at that time to cooperate against the Turkish Cypriot coalition government. ${ }^{47}$ Questions were being raised about the sustainability of the status quo in the northern part of Cyprus, and the only way to end the stalemate was conflict resolution and the accession of a unified Cyprus to the EU. ${ }^{48}$ The policies of the right-wing coalition government and the hard-line stance of the Turkish Cypriot leader Rauf Denktaş on the Cyprus problem met with social opposition and comprised a reason to rally for ending the status quo in the northern part of the island and supporting the conflict resolution attempts. ${ }^{49}$ The first and most important interaction between the EU institutions and Turkish Cypriots occurred following the April 2003 opening of the Green Line checkpoints, when the EU's full support for conflict resolution raised optimism about its contribution to peace and economic prosperity on the island.

Whereas Turkish Cypriots perceived EU membership positively as it would lead to the end of the status quo in the northern part of Cyprus, Greek Cypriot aspirations for EU membership can be understood by tracing back to 1990, the application year of the Republic of Cyprus for EU membership. When the former President of the Republic of Cyprus, George Vassiliou, was elected in 1988, he prioritised the EU membership of Cyprus in his agenda. The change of attitude of the Communist Party, AKEL, in 1990, in favour of EU membership created a positive atmosphere in the Republic of Cyprus. ${ }^{50}$ After the accession talks began in 1998, Greek Cypriot perceptions were also positive towards EU membership. Membership was expected to secure a fair solution to the Cyprus problem, ${ }^{51}$ which would be a 'European solution in accordance with the EU values and the acquis communautaire ${ }^{.}{ }^{52}$ 
Following the significant role played by the Turkish Cypriot media during the bicommunal conflict between the mid-1960s and the mid-1970s, the Turkish Cypriot public sphere was again shaped by another important development, solution prospects for the Cyprus problem and the UN-sponsored Annan Plan. In addition to the opposition political parties and civil society organisations having a key role in mobilising the Turkish Cypriot masses to support the solution of the Cyprus problem and EU accession, the Turkish Cypriot media gained credibility and trust, succeeded in influencing the Turkish Cypriot public sphere and facilitating public deliberation. News about European issues, policies and actors supporting the solution process and EU membership were prevalent. Whereas before 2000, European issues were mostly absent, between 2002 and 2004, statements made by EU officials were widely covered by the Turkish Cypriot media. ${ }^{53}$ Besides this, the discourse used by the Turkish Cypriot political elite in favour of EU accession also shaped the Turkish Cypriot public sphere by creating a perception that the solution of the Cyprus problem and EU membership would bring peace, democracy and economic prosperity to the island. ${ }^{54}$ One of the interviewees explained that 'perceptions towards the solution of the Cyprus problem and being a member of the EU were strong in 2004; during the Annan Plan period, journalists in various media institutions presented television programmes, wrote columns. EU-related issues were covered in headlines. ${ }^{155}$ Hence, the Turkish Cypriot public sphere was replete with information about the EU, and this paved the way for a political breakthrough which would affect the future of Cyprus. Willingness for the solution of the Cyprus issue was matched by positive perceptions towards the EU. The Turkish Cypriot media became one of the main drivers of the political and social change in the Turkish Cypriot community. The reason for this is 'because the society could not find a way to solve domestic political and economic problems themselves in that time. They were looking for an alternative to get rid of those problems, as they lost hope in the Turkish Cypriot administration. Journalists offered an alternative for the Turkish Cypriot community. They identified journalists as the opposition and gave them a mission to raise their voice and put pressure on the political elite. Therefore, Turkish Cypriot society believed that they could not live in isolation from the world anymore, and Turkish Cypriot media would convey their demands to the world which consisted of finding a solution for the Cyprus problem and EU membership'. ${ }^{56}$

Although the Annan Plan failed to solve the Cyprus question in 2004, perceptions of the Turkish Cypriot community remained positively shaped towards the EU, which allowed for a change in the leadership of the community. ${ }^{57}$ The Eurobarometer Survey Data ${ }^{58}$ shows that the positive image of the EU within the Turkish Cypriot community was 57 and 68 per cent in 2004 and 2005, respectively. ${ }^{59}$ In 2005, 48 per cent of Turkish Cypriots viewed EU membership as a catalyst to bring peace and economic prosperity to the island. ${ }^{60}$

While Turkish Cypriots faced big disillusionment with the Annan Plan referendum results which meant for them the continuation of the status quo, the individual and societal links established with the EU could provide them a way out of the pre-existing situation. In parallel with the European Commission proposal and the decision given by the Council of the EU in 2004, Financial Aid and Green Line Regulations were implemented. These would contribute to the economic development in the northern part of Cyprus and deepening bicommunal relations. ${ }^{61}$ Despite the successful implementation of various support programmes which have contributed to the Europeanisation process in the Turkish Cypriot community, the goal of developing a more Europeanised Turkish Cypriot public sphere remained elusive. After the Annan Plan period, Turkish Cypriots were disappointed as there was no political breakthrough. In the views of one interviewee,

The Turkish Cypriot community experienced two traumas at the same time. The first trauma was the promises given that they would get rid of the status quo and a new page would be opened in the island and the second was that although they voted in favour of the Annan Plan, they were punished as nothing changed in the northern part of Cyprus. ${ }^{62}$ 


\section{Europeanisation of national public spheres: the role and influence of media}

Europeanisation marks the pathway and opportunity for EU candidate countries and member states to establish and deepen their relations with the Union. It refers to various processes of adaptation of states to EU policies, norms and values with involvement of different state and non-state actors both at national and supranational levels and is defined as a top-down process in which the national politics of a state is shaped by supranational political and economic dynamics. $^{63}$ In other words, Europeanisation is conceptualised as 'a situation where distinct modes of European governance transform aspects of domestic politics' ${ }^{16}$ by '(a) construction, (b) diffusion, and (c) institutionalisation of formal and informal rules, procedures, policy paradigms, styles, "ways of doing things", and shared beliefs and norms which are first defined and consolidated in the making of EU public policy and politics and then incorporated in the logic of domestic discourse, identities, political structures, and public policies'.65

Europeanisation processes always operate at the level of the public sphere. ${ }^{66}$ In addition to other institutions contributing to the process of Europeanisation, the media functions as a mediating institution which facilitates political communication and agenda setting. ${ }^{67}$ Hence, national public spheres become domains where citizens are informed and involved in deliberation about EU matters. The media act as an institution in the 'liberal democratic' EU polity to contribute to social and political change by facilitating the processes of Europeanisation and European integration through dissemination of information and influencing the public opinion.

The role of the media in contributing to the Europeanisation of national public spheres ${ }^{68}$ is shaped along vertical and horizontal processes of Europeanisation. ${ }^{69}$ Vertical Europeanisation consists of an established linkage between national and supranational actors and institutions. In other words, it refers to the visibility of developments about the EU in the national media. Vertical Europeanisation can be bottom-up when national actors address developments about the EU, and top-down when supranational actors are involved in national public debates on EU issues. ${ }^{70}$ Horizontal Europeanisation refers to the established linkages between different member states. The process of horizontal Europeanisation consists of the media coverage about EU developments in other states. ${ }^{71}$ Thus, horizontal Europeanisation refers to the visibility of developments about the EU in other national public spheres. On the other hand, vertical Europeanisation is usually about the visibility of EU institutions and horizontal Europeanisation focuses on developments in other EU states. ${ }^{72}$ Through both patterns, media influence the Europeanisation of national public spheres by disseminating information and opening new avenues for public deliberation on European issues to take place.

The Turkish Cypriot community has experienced both horizontal and vertical Europeanisation in recent years. In parallel with public deliberation on the Cyprus issue, EU-related issues gained visibility in terms of news coverage. Turkish Cypriots became more informed by the debates about the solution of the Cyprus problem and the contribution of EU membership. Therefore, the salience of the EU topic in the Turkish Cypriot public sphere has always gone in parallel with perceptions about the prospects of a comprehensive solution to the Cyprus problem. Top-down and bottom-up patterns of vertical Europeanisation could be observed in the pre-Annan Plan period, when the Turkish Cypriot community entered in a sui generis relationship with the EU, following the statements by the European Commission and Council of the EU after the Annan Plan referendum. As perceptions towards the EU changed in parallel to the Cyprus negotiations, the role of the Turkish Cypriot media in developing a Europeanised Turkish Cypriot public sphere was also remodelled alongside the relationship between the Turkish Cypriot community and the EU.

\section{Turkish Cypriot media and the EU}

Following the disillusionment brought about by the Annan Plan referendum, Turkish Cypriot media had a key role in shaping perceptions of the Turkish Cypriot community towards the EU. 
Trust placed in the Turkish Cypriot media in 2004 and 2005 was much higher than that of Turkish Cypriot political parties, local authorities and other domestic institutions. ${ }^{73}$ This could help transform perceptions about the EU (Figure 1).

Nevertheless, the record of the Turkish Cypriot media in the post-Annan Plan period was rather poor. As one interviewee said,

As the Turkish Cypriot media, we strongly disseminated information that the continuation of the status quo was not our fault, because we did our best in the Annan Plan referendum. There were others to be blamed, and one of the institutions to be blamed was the European Union. Thus, we created a perception in the society that the status quo could be sustainable. ${ }^{74}$

Moving away from the atmosphere created during the Annan Plan period also led the Turkish Cypriot media to distance itself from EU-related issues. This influenced news coverage about the EU. Whereas developments at the supranational level to be introduced in the Turkish Cypriot public sphere have met with diminished interest, attention given to actors, institutions and developments related to the EU in other member states has been associated and compared with the Republic of Cyprus. The reason for decreasing interest in EU issues by the Turkish Cypriot media was also linked to the suspension of implementation of EU legislation in the northern part of Cyprus. As economic and social policies implemented by the EU authorities upon member states are not binding in the northern part of Cyprus, the daily lives of Turkish Cypriots were not affected. Hence, the visibility of European politics has remained limited within the context of the solution prospects of the Cyprus problem, both at the national and supranational levels. ${ }^{75}$ One interviewee stated that:

The relationship between the Turkish Cypriot community and the EU has remained based on the attempts to provide economic development in the northern part of Cyprus and to find a solution to the Cyprus problem. This type of limited relationship also has restricted the role of the Turkish Cypriot media in contributing to the Europeanisation process by explaining the principles and values which the EU is built on. We were willing to disseminate more information about the democratic principles, human rights, environmental policies within the context of the EU, but the EU did not also put sufficient effort into this issue or we were unsuccessful as Turkish Cypriot media in establishing this type of dialogue with the EU. ${ }^{76}$

Another interviewee argued as follows:

We did not even talk about the results of these projects which were supposed to increase the economic development and bicommunal dialogue. We did not provide enough space in our media to explain them to our society. We did not give enough attention to explain these efforts to the people. Hence, this

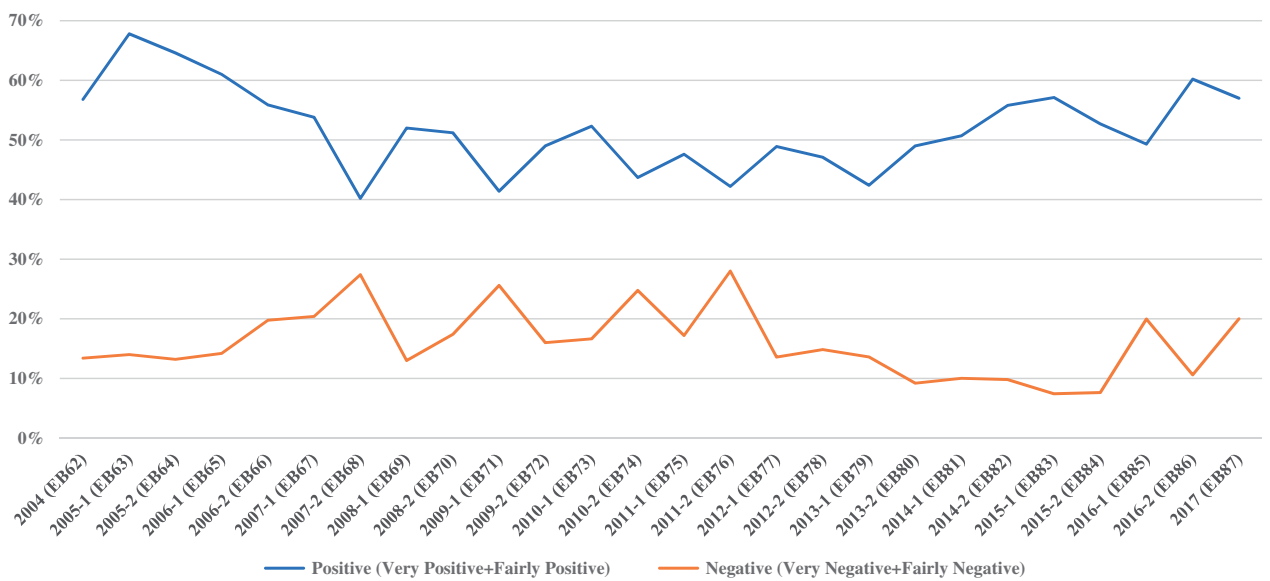

Figure 1. Trust in Institutions in the Turkish Cypriot Community Question: How much trust do you have in the following media and institutions? Source: European Commission Standard Eurobarometer Surveys on Turkish Cypriot Community. 
relationship has remained based on economic interests and shaped along the solution prospects for the Cyprus problem. ${ }^{77}$

Therefore, the role of the Turkish Cypriot media influenced the public perceptions of the Turkish Cypriot community. The Eurobarometer Survey Results indicated that the positive image of the EU for the Turkish Cypriot community sharply decreased from 68 to 40 per cent between 2005 and $2007 .^{78}$ Perceptions that the EU would foster peace fell from 47 to 19 per cent between 2006 and 2009. ${ }^{79}$ Despite the regulations implemented to improve economic conditions in the northern part of Cyprus, Turkish Cypriot perceptions vis-à-vis the EU deteriorated between 2005 and 2011 (Figure 2). ${ }^{80}$

The role of the Turkish Cypriot media in shaping the Turkish Cypriot public sphere during the Europeanisation process was also closely related to the weaknesses in the institutionalisation of the Turkish Cypriot media. Interviews with Turkish Cypriot media representatives have revealed that one of the important difficulties experienced has been limited access to EU-related information. Turkish Cypriot media depended on the information provided by the news agencies. ${ }^{81}$ It has been explained that 'our resources to get information about the developments in the EU are very limited. We are dependent on online sources or news agencies. Because we have limited access to information about EU-related issues, the news that we give place in the Turkish Cypriot media remain limited to the Cyprus problem or developments in the Republic of Cyprus about the European Union. ${ }^{82}$ It is also observed that Turkish Cypriot media institutions do not have specific units or journalists who closely follow European issues. ${ }^{83}$ Once more, having limited access to EU-related information and the lack of staff employed to follow European issues are closely dependent on aspects of the relationship established between the Turkish Cypriot community and the EU. As the implementation of EU legislation remains suspended in the northern part of Cyprus, daily political, economic and social developments in Europe or decisions taken by the EU institutions do not have a binding effect on the Turkish Cypriot community or impact on people's daily lives. Therefore, EU-related developments do still fall into the category of 'foreign news', and Turkish Cypriot news media institutions do not find it a requirement to develop closer links with the EU. ${ }^{84}$ On the other hand, many of the Greek Cypriot news media institutions employ personnel in Cyprus or have staff based in Brussels who closely follow what is happening in the $\mathrm{EU}^{85}$

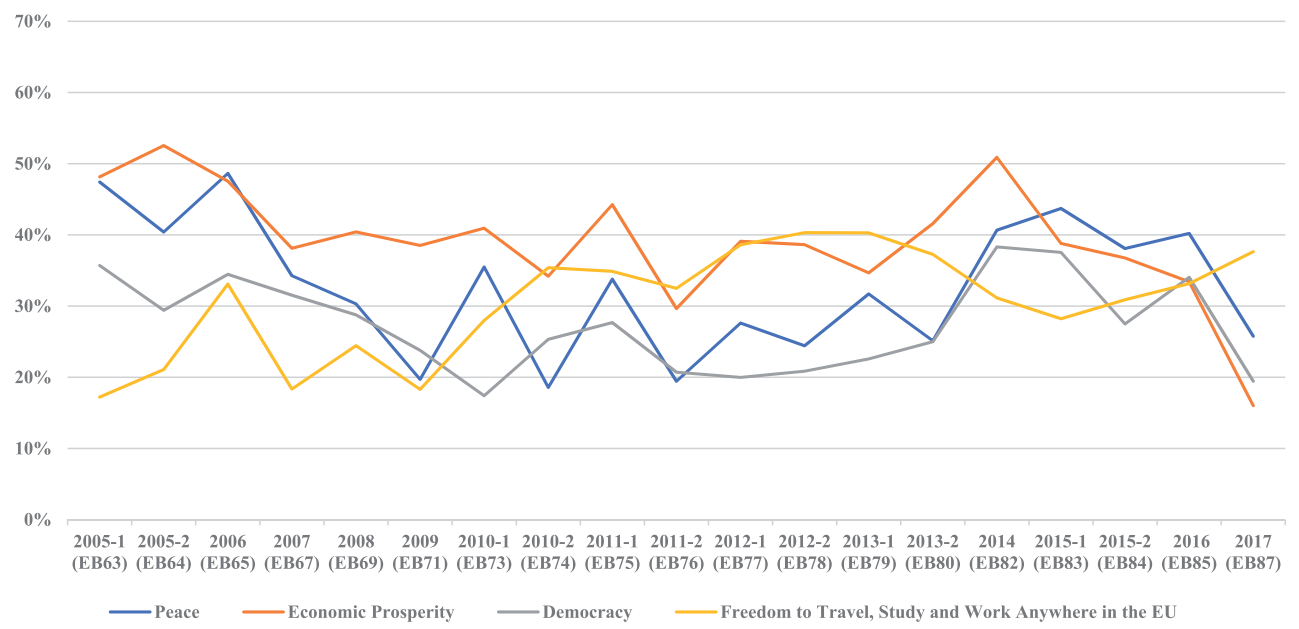

Figure 2. Image of the EU for the Turkish Cypriot Community Question: In general, does the EU conjure up for you a very positive, fairly positive, neutral, fairly negative or very negative image? Source: European Commission Standard Eurobarometer Surveys on Turkish Cypriot Community. 
The last difficulty observed through the weaknesses in institutional development of the Turkish Cypriot media is the language barrier. As Turkish is not among the EU official languages, the number of documents prepared by the EU institutions and translated into Turkish remain very limited. Apart from non-English speaking Turkish Cypriots who cannot follow EU-related developments because of the language barrier, skilled personnel and additional financial resources for the Turkish Cypriot media institutions are also needed to perform the task of translation before including European issues in news coverage. Nevertheless, it is stated that 'there are positive developments in overcoming this problem, as many young journalists, educated in various parts of Europe, are returning to Cyprus and they are employed in different media institutions'. ${ }^{86}$

Another important step forward achieved in the post-Annan Plan period through the sui generis relationship established between the Turkish Cypriot community and the EU is the improved representation of Turkish Cypriot media associations and unions in Europe and cooperation with the EU representation offices in Cyprus. The Turkish Cypriot Journalists Association (Kıbrıs Türk Gazeteciler Birligi) has played a significant role in this process. The Association has continued to increase its collaboration with its counterparts in the Republic of Cyprus and there have been many workshops, exchange programmes, and information sessions organised in Brussels or Cyprus, hosted by the EU institutions or representation offices. ${ }^{87}$ Similarly, the Turkish Cypriot Press Workers Union (Kıbrıs Türk Basın Emekçileri Sendikası) became a member of the Association of European Journalists. Since 2015, the Union has been involved in the decision-making processes in the executive units of the Association of European Journalists, in collaboration with its counterpart in the Republic of Cyprus. ${ }^{88}$

The positive image of the $\mathrm{EU}$ in the Turkish Cypriot public sphere fluctuated between 40 and 60 per cent between 2007 and $2017 .{ }^{89}$ Similarly, it has been shown that since 2014 the EU is perceived less as a catalyst contributing to the peace process and fostering economic prosperity on the island. ${ }^{90}$ One of the important causal mechanisms leading to these perceptions is established by the role of the Turkish Cypriot media in influencing perceptions of the Turkish Cypriot community towards the EU. As the Turkish Cypriot media was successful in shaping the Turkish Cypriot public sphere positively towards the EU during the pre-Annan Plan period, it has been very difficult to come up with the same argument after 2004 (Figure 3).

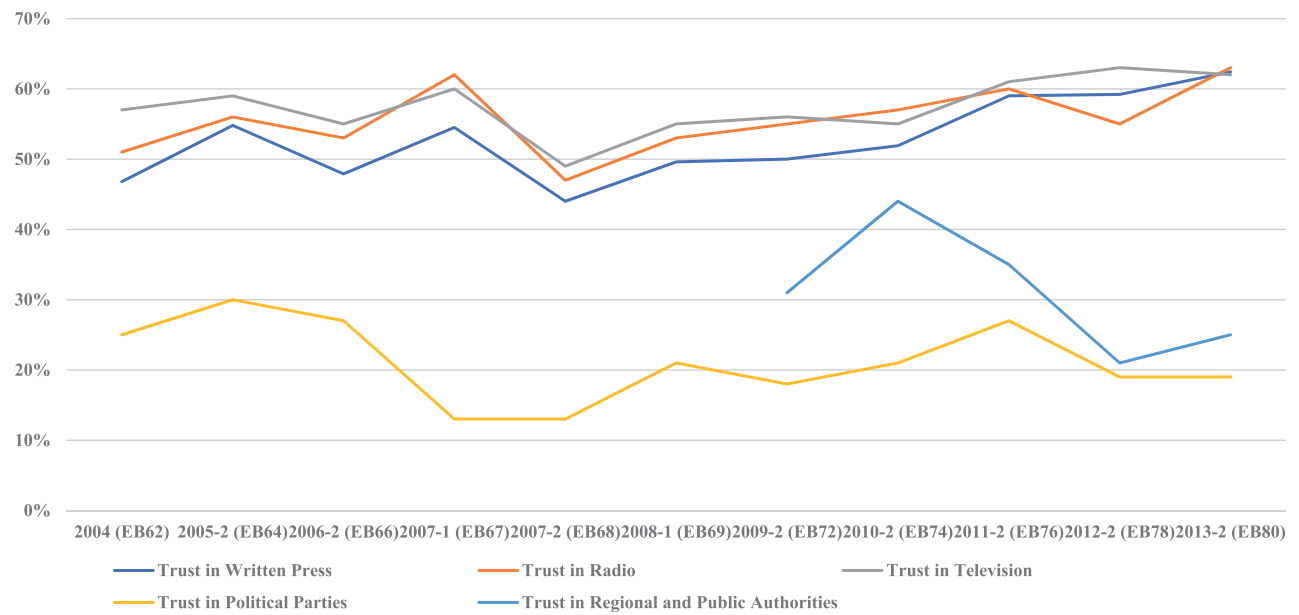

Figure 3. Meaning of the EU Personally for the Turkish Cypriot Community Question: What does the EU mean to you personally? Source: European Commission Standard Eurobarometer Surveys on Turkish Cypriot Community. 


\section{Conclusion: Turkish Cypriot media and the Europeanisation of the local public sphere}

The analysis of the Turkish Cypriot media in shaping the Turkish Cypriot public sphere through the process of Europeanisation reveals interesting results with regards to the contrasting role played in the pre- and post-Annan plan periods. Whereas Turkish Cypriot media was successful in positively influencing Turkish Cypriot public opinion towards the EU during the Annan Plan period, it is very hard to argue the same when the latter period is considered, despite a sui generis relationship established between the Turkish Cypriot community and the EU.

First, the role of the Turkish Cypriot media in shaping the Turkish Cypriot public sphere towards the EU has continued to be in parallel with developments in the Cyprus negotiations. This has led the Turkish Cypriot media to only disseminate information about EU-related issues associated with the Cyprus negotiations. Therefore, other political, economic and social developments at the supranational level or in other member states could barely find the chance to be disseminated in the public sphere, as the interviews presented above reveal. As top-down Europeanisation would suggest, only EU actors and institutions have been covered in the news when there is a development about the Cyprus issue and quotes given by the Turkish Cypriot political elite to the EU actors and institutions have remained restricted to conflict resolution attempts, as the bottom-up approach of Vertical Europeanisation suggests. In terms of the patterns of horizontal Europeanisation, Turkish Cypriot media have started referring to developments in the Republic of Cyprus . Hence, EU-related issues have been included in news coverage based on statements made by the Greek Cypriot politicians and opinion makers and in the context of the Cyprus problem. The impact of day-to-day EU policies on the Greek Cypriot community has also led to increased Greek Cypriot news media coverage of other EU member state policies.

This leads to a deeper analysis of the weak institutionalisation of the Turkish Cypriot media and the extent of the progress achieved through the Europeanisation process. One of the main difficulties encountered is limited access to resources. Most of the Turkish Cypriot media organisations have neither specific units nor personnel specifically interested in European issues, unlike the Greek Cypriot media organisations. Hence, the EU-related news coverage has remained part of 'foreign news' and there is limited dissemination of more information in the Turkish Cypriot public sphere. Another crucial factor lies in the language barrier. As Turkish is not among the official languages of the EU, Turkish Cypriot media organisations need more skilled personnel and additional financial resources to fulfil the translation task. That obstacle also affects the EUrelated coverage in the Turkish Cypriot media. Despite these institutional weaknesses, organisations such as the Turkish Cypriot Journalists Association and the Turkish Cypriot Press Workers Union have succeeded in improving their representation at the supranational level.

The lack of a solution in the Cyprus problem still creates many obstacles to the Europeanisation process of the Turkish Cypriot community. The sui generis relationship established between Turkish Cypriots and the EU requires the strong involvement of the Turkish Cypriot media to contribute to the Europeanisation process in the northern part of Cyprus and a more Europeanised public sphere. However, weak institutionalisation and capacity problems negatively affect the potential role of the Turkish Cypriot media. Capacity-building and stronger cooperation between pro-EU, pro-solution media and non-governmental organisations (NGOs) across the Green Line appears imperative for a stronger contribution of the Turkish Cypriot media to the Europeanisation of the Turkish Cypriot community.

\section{Acknowledgements}

Some of the data and arguments proposed in this article are derived from Cagkan Felek's thesis supervised by the lead author. 


\section{Disclosure statement}

No potential conflict of interest was reported by the authors.

\section{ORCID}

loannis N. Grigoriadis (iD http://orcid.org/0000-0003-0882-6125

Cagkan Felek (iD) http://orcid.org/0000-0002-1221-8539

\section{Notes}

1. The term 'media' in this article includes print and online newspapers, television and radio channels.

2. D. Geldenhuys, Contested States in World Politics (London, UK: Palgrave Macmillan, 2009), p.1.

3. The Annan Plan was introduced by the United Nations as a comprehensive solution to the Cyprus problem. It was named after the United Nations Secretary-General Kofi Annan. The plan proposed a bi-zonal, bicommunal federal Cyprus. It was revised five times between 2002 and 2004 and was submitted to a double referendum on 24 April 2004.

4. G. Kyris, 'A Model of "Contested" Europeanization: The European Union and the Turkish-Cypriot Administration', Comparative European Politics, Vol.12, No.2 (2014), p.161; G. Kyris, 'Europeanisation Beyond Contested Statehood: The European Union and Turkish-Cypriot Civil Society', Journal of Common Market Studies, Vol.51, No.5 (2013), p.867; George Kyris, 'Europeanisation and the Turkish-Cypriot Political Parties: How Europe Matters?', Turkish Studies, Vol.13, No.3 (2012), p.482.

5. C. de la Porte and A. van Dalen, 'Europeanization of National Public Spheres? Cross-National Media Debates About the European Union's Socio-Economic Strategy', European Politics and Society, Vol.17, No.3 (2016), pp.1-2.

6. As framed by G. Kyris, The Europeanisation of Contested Statehood: The EU in Northern Cyprus (London, UK: Ashgate Publishing Ltd., 2015); Kyris, 'A Model of 'Contested' Europeanization: The European Union and the Turkish-Cypriot Administration'; Kyris, 'Europeanisation Beyond Contested Statehood: The European Union and Turkish-Cypriot Civil Society'.

7. It is expected that with the comprehensive solution of the Cyprus problem, EU legislation will be fully applied in the whole island.

8. Other contested states are given as Abkhazia, Kosovo, Somaliland, Palestine, Western Sahara and Taiwan. See Geldenhuys, Contested States in World Politics, p.2.

9. European Commission, Press Release: European Commission Proposes Visa-Free Travel for the People of Kosovo, published on 4 May 2016, available from http://europa.eu/rapid/press-release_IP-16-1626_en.htm.

10. European Parliament, European Parliament Resolution on Recognition of Palestine Statehood, published on 17 December 2014, available from http://www.europarl.europa.eu/news/en/press-room/20141212IPR01105/ european-parliament-resolution-on-recognition-of-palestine-statehood; B.O. Martins, "'A Sense of Urgency": The EU, EU Member States and the Recognition of the Palestinian State', Mediterranean Politics, Vol.20, No.2 (2015), pp.281-82.

11. C. Dodd, The History and Politics of the Cyprus Conflict (London, UK: Palgrave Macmillan, 2010), p.44.

12. For more information about the Greek Cypriot proposals to change the Constitution of the Republic of Cyprus, see ibid., pp.48-51.

13. N. Nugent, 'Cyprus and the European Union: A Particularly Difficult Membership Application', Mediterranean Politics, Vol.2, No.3 (1997), p.55.

14. K. Featherstone, 'Cyprus and the Onset of Europeanization: Strategic Usage, Structural Transformation and Institutional Adaptation', South European Society and Politics, Vol.5, No.2 (2000), pp. 142-43.

15. T. Diez, 'Why the EU Can Nonetheless Be Good for Cyprus', Journal of Ethnopolitics and Minority Issues in Europe, Vol. 3, No. 2 (2002), p.3; G. Christou, The European Union and Enlargement: The Case of Cyprus (London, UK: Palgrave Macmillan, 2004), p.62.

16. A. Çarkoğlu and A. Sözen, 'The Turkish Cypriot General Elections of December 2003: Setting the Stage for Resolving the Cyprus Conflict?', South European Society and Politics, Vol.9, No.3 (2004), p.130.

17. For the full text of the Annan Plan, see United Nations, United Nations Website of the Secretary-General's Comprehensive Peace Plan for Cyprus - The 'Annan Plan', published on 6 April 2004, available from http:// www.hri.org/docs/annan/. For a summary of the Annan Plan, see Christou, The European Union and Enlargement: The Case of Cyprus, pp.191-98, C. Dodd, The History and Politics of the Cyprus Conflict, pp.223-54.

18. Council of the European Union, Council Regulation (EC) No 866/2004 of 29 April 2004 on a Regime under Article 2 of Protocol 10 to the Act of Accession, published on 29 April 2004, available from http://eur-lex.europa.eu/ LexUriServ/LexUriServ.do?uri=OJ:L:2004:206:0051:0056:EN:PDF. 
19. European Commission, Commission Statement Following the Outcome of the Referendum in Cyprus, published on 24 April 2004, available from http://europa.eu/rapid/press-release_IP-04-537_en.htm?locale=en.

20. Council of the European Union, General Affairs Council of the European Union Statement on the Policy of the European Union with Regard to the Turkish Cypriot Community, published on 26 April 2004, available from http://europa.eu/rapid/press-release_PRES-04-115_en.htm.

21. The first two pages of the Kypros/Cyprus were in English and other two pages were in Greek. On this, see A. An, 'The British Rule in Turkish Cypriot Text-Books and Turkish Cypriot Text-Books in Cyprus', The Cyprus Review, Vol.6, No.1 (1994), p.65; M. Demiryürek, 'Turkish Cypriot Press and the Turkish Governments I, Ottoman Period, 1878-1910 (Kıbrıs Türk Basını Ve Türkiye Hükümetleri I, Osmanlı Dönemi, 1878-1910)', Ankara University, Institute of Turkish Reform History, The Journal of Atatürk Yolu (Ankara Üniversitesi Türk Inkılap Tarihi Enstitüsü, Atatürk Yolu Dergisi), Vol.25-26 (2000), p.120.

22. Demiryürek, 'Turkish Cypriot Press and the Turkish Governments I, Ottoman Period, 1878-1910 (Kıbrıs Türk Basını Ve Türkiye Hükümetleri I, Osmanlı Dönemi, 1878-1910)', p.121.

23. Turkish Republic of Northern Cyprus Public Information Office, Cyprus Turkish Press History (Kıbrıs Türk Basınının Tarihi), available from http://pio.mfa.gov.ct.tr/medya-rehberi/kibris-turk-basin-tarihi/; Demiryürek, 'Turkish Cypriot Press and the Turkish Governments I, Ottoman Period, 1878-1910 (Kıbrıs Türk Basını Ve Türkiye Hükümetleri l, Osmanlı Dönemi, 1878-1910)', pp.121-22.

24. P. Gürçınar, 'The Origins of the Turkish Cypriot Printing, the Stages of Its Modernisation Process and an Experimental Study on the Effects of These Stages on the Turkish Cypriot Community in the History of Cyprus (Kıbrıs Türk Tarihi iç̧erisinde Kıbrıs Türk Matbaacılığının Doğuşu, Geçirdiği Modernleşme Aşamaları Ve Bu Aşamaların Kıbrıs Türk Toplumuna Etkileri Üzerine Bir Deneme)', The Journal of International Social Research (Uluslararası Sosyal Arastırmalar Dergisi), Vol.7, No.31 (2014), pp.341-42; A. An, History of Turkish Cypriot Press II: The List of Published Newspapers and Journals in Turkish in Cyprus, 1878-2013 (Kıbrıs Türk Basın Tarihi II: Kıbrıs'ta Türkçe Basılmış Gazete Ve Dergiler Listesi, 1878-2013) (Nicosia, Cyprus: Söylem Agency and Printing Services and Turkish Cypriot Librarians Association, 2013), p.19.

25. It is important to note that Turkish Cypriot political elites involved in printing these newspapers were not professional journalists. They were mostly teachers, lawyers, doctors or trade persons. The reasons for this are that they were literate and wealthy people. See Turkish Cypriot Journalists Association (Kıbrıs Türk Gazeteciler Birligi), History of the Turkish Cypriot Press (Kıbrıs Türk Basın Tarihi) (Nicosia, Cyprus: Söylem Printing House, 2012), p.23.

26. B. Evre, The Emergence and Development of the Turkish Cypriot Nationalism (Kıbrıs Türk Milliyetçiliği Oluşumu Ve Gelişimi) (Nicosia, Cyprus: Işık Printing House, 2004), p.46.

27. Names of these newspapers were Ümid, Saded, Dik-i Şarki, Zaman, Yeni Zaman, Kıbrıs, Kokonoz, Akbaba, Feryad, Mirat-ı Zaman, Sünuhat, Sada-ı Kıbrıs, İslam, Vatan, Seyf, Kıbrıs, Doğruyol, Hakikat, Ankebut, Vatan, Söz, Davul, Birlik, Masum Millet. See An, History of Turkish Cypriot Press II: The List of Published Newspapers and Journals in Turkish in Cyprus, 1878-2013 (Kıbrıs Türk Basın Tarihi II: Kıbrıs'ta Türkçe Basılmış Gazete Ve Dergiler Listesi, 1878-2013), pp.19-28.

28. Turkish Republic of Northern Cyprus Public Information Office, Cyprus Turkish Press History (Kıbrıs Türk Basınının Tarihi). For more information about these newspapers, see H. Fedai and A. An, History of the Turkish Cypriot Press Explained with Examples I, 1891-1963 (Örnekleriyle Kıbrıs Türk Basın Tarihi I, 1891-1963) (Nicosia, Cyprus: TipografArt Publishing House, 2012), pp.41-68.

29. The Turkish Cypriot community closely followed the reforms applied after the establishment of the Republic of Turkey in 1923. The Alphabet Reform (Harf Devrimi) was one of them. Söz and Masum Millet were the first two newspapers that shifted to the Latin alphabet. See Turkish Cypriot Journalists Association (Kıbrıs Türk Gazeteciler Birliği), History of the Turkish Cypriot Press (Kıbrıs Türk Basın Tarihi), pp.10, 22.

30. Ibid., pp.66-67; A.C. Sophocleous, 'The First Cypriot Newspapers and the British', Global Media Journal: Mediterranean Edition, Vol.1, No.1 (2006), pp.118-21.

31. The publication policy of the newspaper was defined by Küçük as to 'inform the public about the developments happening in the world' and 'to be the proud voice of the Turk' (Halkın Sesi Gazetesi, Türk'ün onurlu ve şerefli sesi olacaktır). See Fedai and An, History of the Turkish Cypriot Press Explained with Examples I, 1891-1963 (Örnekleriyle Kıbrıs Türk Basın Tarihi I, 1891-1963), pp.68-69.

32. Küçük became the first Vice-President of the Republic of Cyprus in 1960.

33. Ö. Çatal, 'The Broadcasting Policies, Ownership and News Production Processes of the Radio and Television Channels Operating in Turkish Republic of Northern Cyprus (Kuzey Kıbrıs Türk Cumhuriyeti Radyo Ve Televizyon Kanallarının Yayın Politikaları, Sahiplik Yapısı Ve Haber Üretim Süreçleri)', The Journal of Global Communication (Küresel Iletişim Dergisi), Vol. 1 (2006), p.2.

34. Turkish Cypriot Journalists Association (Kıbrıs Türk Gazeteciler Birliği), History of the Turkish Cypriot Press (Kıbrıs Türk Basın Tarihi), pp.10, 104-05.

35. An, History of Turkish Cypriot Press II: The List of Published Newspapers and Journals in Turkish in Cyprus, 1878-2013 (Kıbrıs Türk Basın Tarihi II: Kıbrıs'ta Türkçe Basılmış Gazete Ve Dergiler Listesi, 1878-2013), pp.63, 65, $73,80$. 
36. Turkish Republic of Northern Cyprus Public Information Office, Cyprus Turkish Press History (Kıbrıs Türk Basınının Tarihi). Although, Radio Bayrak started to broadcast during the period of intercommunal conflict and following 1983, it came under public control with Bayrak TV and operated under the institutional umbrella of Bayrak Radio and Television Corporation (Bayrak Radyo Televizyon Kurumu).

37. Ibid., Turkish Cypriot Journalists Association (Kıbrıs Türk Gazeteciler Birligi), History of the Turkish Cypriot Press (Kıbrıs Türk Basın Tarihi), pp.343-48.

38. Turkish Republic of Northern Cyprus Public Information Office, Cyprus Turkish Press History (Kıbrıs Türk Basınının Tarihi); Turkish Cypriot Journalists Association (Kıbrıs Türk Gazeteciler Birliği), History of the Turkish Cypriot Press (Kıbrıs Türk Basın Tarihi), pp.335-42.

39. The main newspapers printed in that period were Barış, Yenidüzen, Yarın, Kurtuluş, Yön, Söz, Halkçı, Turan, Birlik, Ortam, Haber, Özgürlük, Demokrat, Mücahit, Kıbrıs, Avrupa, Kıbrıslı, Volkan, Birleşik Kıbrıs, Sözcü, Çivi, Kıbrıs Star, Demokrat Bakış, Havadis, Haberdar, and Gelecek. See Turkish Cypriot Journalists Association (Kıbrıs Türk Gazeteciler Birliği), History of the Turkish Cypriot Press (Kıbrıs Türk Basın Tarihi), pp.130-31.

40. M. Ersoy, Dominant Peace/Conflict Frames of Opinion Articles in the Turkish Cypriot Press in T. Ilter, H. Aliefendioğlu, P. Behçetoğulları and N. Kara (eds.), (Re)Making and Undoing of Peace/Conflict (Famagusta, Cyprus: Eastern Mediterranean University Press, 2013), pp.77-78.

41. The names of the main TV channels operating in the northern part of Cyprus are 'Ada, Bayrak 1, Bayrak 2, Diyalog, Genç, Tempo, Kıbrıs, Sim' (authors' compilation from various sources and interviews).

42. The names of the main radio channels operating in the northern part of Cyprus are 'Ada, Bayrak 1, Bayrak International, Bayrak, Bayrak Haber, Bayrak Müzik, Diyalog, First, Inter First, Havadis, Kıbrıs, Vatan, Güven, Mayıs, Tempo, Sim' (authors' compilation from various sources and interviews).

43. The names of the main newspapers printed in the northern part of Cyprus are 'Afrika, Demokrat Bakış, Detay, Diyalog, Volkan, Güneş, Haberal Kıbrıslı, Haberatör, Hakikat, Halkın Sesi, Havadis, Kıbrıs, Kıbrıs Manşet, Kıbrıs Postası, Ortam, Star Kıbrıs, Vatan, Yeni Bakış, Yenidüzen' (authors' compilation from various sources and interviews).

44. The names of the main online news portals in the northern part of Cyprus are 'Ada Basını, Gündem Kıbrıs, Haber Kıbrıs, Kıbrıs 7/24, Kıbrıs Postası, Kıbrıs Son Dakika, Kıbrıs Time, KKTC Haber, KKTC Medya' (authors' compilation from various sources and interviews).

45. These organizations are the Turkish Cypriot Journalists Association (Kıbrıs Türk Gazeteciler Birliği), Turkish Cypriot Sports Columnists Association (Kıbrıs Türk Spor Yazarları Derneği), Turkish Cypriot Press Workers' Union (Kıbrıs Türk Basın Emekçileri Sendikası), Bayrak Radio and Television Workers' Union (Bayrak Radyo-Televizyon Çalışanları Sendikası), Turkish Cypriot Cartoonists Association (Kıbrıs Türk Karikatürcüler Derneği), External Press Association (Dış Basın Birliği), News Cameramen's Association (Haber Kameramanları Birliği) (authors' compilation from various sources and interviews).

46. H. Lacher and E. Kaymak, 'Transforming Identities: Beyond the Politics of Non-Settlement in North Cyprus', Mediterranean Politics, Vol.10, No.2 (2006), p.157.

47. Çarkoğlu and Sözen, 'The Turkish Cypriot General Elections of December 2003: Setting the Stage for Resolving the Cyprus Conflict?', pp.130-33.

48. For more information on these demonstrations, see Newsdesk, From Nicosia to New York: Solution (Lefkoşa'dan New York'a: Çözüm), published on 11 February 2004, available from http://arsiv.kibrisgazetesi.com/?p=181454; Newsdesk, Again, We Will Be at the Inönü Square Tomorrow (Yarın Yine Meydanlardayız), published on 13 April 2004, available from http://arsiv.kibrisgazetesi.com/?p=228349; Newsdesk, Historical Message (Tarihi Mesaj), published on 15 April 2004, available from http://arsiv.kibrisgazetesi.com/? $\mathrm{p}=228757$.

49. Christou, The European Union and Enlargement: The Case of Cyprus, pp.112-1, Lacher and Kaymak, 'Transforming Identities: Beyond the Politics of Non-Settlement in North Cyprus', pp.157-59.

50. K. Agapiou-Josephides, 'Changing Patterns of Euroscepticism in Cyprus: European Discourse in a Divided Polity and Society', South European Society and Politics, Vol.16, No.1 (2011), p.169.

51. Ibid., p.162.

52. T. Diez and N. Tocci, 'The Cyprus Conflict and the Ambiguous Effects of Europeanisation', The Cyprus Review, Vol.22, No.2 (2010), p.182.

53. S. Özuslu, 'Chief Editor of Sim TV and Sim Radio, President of the Turkish Cypriot Journalists Association' (Face-to-Face Interview, translated into English from Turkish, conducted in United Media Group Headquarters, Nicosia, Cyprus, on 28 December 2017). Sim Radio is a private institution which was founded in 1998 and had an important mission by positively influencing Turkish Cypriot public opinion in the Annan Plan period, in addition to other media organisations. It was followed by the foundation of Sim TV in 2008. In 2009, Sim Radio, Sim TV and Yenidüzen Newspaper were gathered together under the United Media Group. Sim TV is the only media institution which has an official partnership with Europarl TV. See Turkish Cypriot Journalists Association (Kıbrıs Türk Gazeteciler Birligi), History of the Turkish Cypriot Press (Kıbrıs Türk Basın Tarihi), p.381.

54. The main opposition party, the Republican Turkish Party (Cumhuriyetçi Türk Partisi) played a key role in mobilising masses during the Annan Plan in collaboration with other Turkish Cypriot political parties and civil society organizations. Slogans used at that time were 'With One Yes Vote, You Will Be Connected to Europe! (Bir Evet Ile Avrupa'ya Bağlan!)' and 'Now, Yes to Europe! (Avrupa Şimdi, Evet!)'. For more information on the 
Turkish Cypriot political landscape between 2003 and 2005, see A. Sözen, 'The Turkish Cypriot Legislative Election of February 2005: The Rise of CTP/BG', South European Society and Politics, Vol.10, No.3 (2005), pp. 465-75.

55. Sami Özuslu, 'Chief Editor of Sim TV and Sim Radio, President of the Turkish Cypriot Journalists Association'.

56. Başaran Düzgün, 'Chief Editor of Havadis Newspaper and Radio Havadis' (Face-to-Face Interview, translated into English from Turkish, conducted in Havadis Media Group Headquarters, Nicosia, Cyprus, on 29 December 2017). Havadis Newspaper is a privately-owned newspaper, founded in 2009. The main publication policy of the newspaper is explained as 'to protect the interests of the Turkish Cypriot community and to take sides on behalf of the solution of the Cyprus problem and peace process' and its slogan is 'a Newspaper Prepared and Printed by Journalists (Gazetecilerin Gazetesi)'. See Turkish Cypriot Journalists Association (Kıbrıs Türk Gazeteciler Birliği), History of the Turkish Cypriot Press (Kıbrıs Türk Basın Tarihi), p.254.

57. Mehmet Ali Talat was elected as the Leader of the Turkish Cypriot community in 2005. He was the former President of the Republican Turkish Party (Cumhuriyetçi Türk Partisi). See Sözen, 'The Turkish Cypriot Legislative Election of February 2005: The Rise of CTP/BG' .

58. It is important to note that Eurobarometer data on the Turkish Cypriot community have only been available since 2004, the year of the EU accession of the Republic of Cyprus.

59. European Commission, European Commission Standard Eurobarometer Survey on Turkish Cypriot Community No. 62, 63, 2004-05b, available from http://ec.europa.eu/COMMFrontOffice/publicopinion/index.cfm/Survey/ index\# $\mathrm{p}=1$ \&instruments $=$ STANDARD.

60. European Commission, European Commission Standard Eurobarometer Survey on Turkish Cypriot Community No. 63, 2005, available from http://ec.europa.eu/COMMFrontOffice/publicopinion/index.cfm/Survey/index\#p=1 \&instruments=STANDARD.

61. See European Commission, Green Line Regulation: Commission Welcomes Council Adoption of Measures That Further Facilitate Trade across the Green Line in Cyprus, published on 17 February 2005, available from http:// europa.eu/rapid/press-release_IP-05-197_en.htm?locale=en; European Commission, Proposal for a Council Regulation on Special Conditions for Trade with Those Areas of the Republic of Cyprus in Which the Government of the Republic of Cyprus Does Not Exercise Effective Control, published on 7 July 2004, available from http:// eur-lex.europa.eu/LexUriServ/LexUriServ.do?uri=COM:2004:0466:FIN:EN:PDF; Council of the European Union, Council Regulation (EC) No. 389/2006 of 27 February 2006 Establishing an Instrument of Financial Support for Encouraging the Economic Development of the Turkish Cypriot Community and Amending Council Regulation (EC) No. 2667/2000 on the European Agency for Reconstruction, published on 27 February 2006, available from http://eur-lex.europa.eu/legal-content/EN/TXT/?uri=CELEX:32006R0389.

62. Cenk Mutluyakalı, 'Chief Editor of Yenidüzen Newspaper' (Face-to-Face Interview, translated into English from Turkish, conducted in United Media Group Headquarters, Nicosia, Cyprus, on 27 December 2017). Yenidüzen was founded by cadres of the Republican Turkish Party (Cumhuriyetçi Türk Partisi) in 1975. Although it was printed weekly, from 1983 it began to be printed daily. The main publication policy of the newspaper is explained that 'Yenidüzen supports the peaceful solution of Cyprus under the umbrella of the federal and bicommunal Republic of Cyprus. Yenidüzen as a newspaper in which democratic forces are organized supports peace at home and peace in the world.' See Turkish Cypriot Journalists Association (Kıbrıs Türk Gazeteciler Birliği), History of the Turkish Cypriot Press (Kıbrıs Türk Basın Tarihi), pp.230-31.

63. T. Börzel and T. Risse, 'When Europe Hits Home: Europeanization and Domestic Change', European Integration Online Papers, Vol.15, No.4 (2000), p.1; R. Ladrech, 'Europeanization of Domestic Politics and Institutions: The Case of France', Journal of Common Market Studies, Vol.32, No.1 (1994), p.69.

64. J. Buller and A. Gamble, 'Conceptualising Europeanisation', Public Policy and Administration, Vol.17, No.2 (2002), p.18.

65. Claudio Radaelli, The Europeanisation of Public Policy in K. Featherstone and C. Radaelli (eds.), The Politics of Europeanization (Oxford, UK: Oxford University Press, 2003), p.30.

66. The concept of 'public sphere' was developed in the writings of Jürgen Habermas. Habermas, in a normative liberal democratic society, explains public sphere as 'made up of private people gathered together as a public and articulating the needs of society with the state'. See J. Habermas, The Structural Transformation of the Public Sphere: An Inquiry into a Category of Bourgeois Society (Berlin, Germany: Polity Press, 1991), p.176.

67. Habermas gives importance to the role of the media because the media functions as a mediator in providing information and can influence people who receive the information. See J. Habermas, S. Lennox and F. Lennox, 'The Public Sphere: An Encyclopedia Article (1964)', New German Critique, No.3 (1974), p.53.

68. Related to the 'democratic deficit' question raised within the European polity, there is an on-going discussion about the possibility of creating a common Europeanised public sphere or whether the processes of Europeanization contribute to the Europeanised national public spheres or whether the Europeanization of national public spheres leads to the development of a common Europeanised public sphere. For a discussion on this, see J. Gerhards, Missing a European Public Sphere in M. Kohli and M. Novak (eds.), Will Europe Work? Integration, Employment and the Social Order (London, UK: Routledge, 2001), pp. 145-58; O. Baisnée, 'The 
European Public Sphere Does Not Exist (at Least It's Worth Wondering...)', European Journal of Communication, Vol.22, No.4 (2007), pp. 493-503.

69. R. Koopmans and J. Erbe, 'Towards a European Public Sphere? Vertical and Horizontal Dimensions of Europeanized Political Communication', Innovation: The European Journal of Social Science Research, Vol.17, No.2 (2004), pp.99-105; R. Koopmans and P. Statham, Theoretical Framework, Research Design and Methods in R. Koopmans and P. Statham (eds.), The Making of a European Public Sphere: Media Discourse and Political Contention (Cambridge, UK: Cambridge University Press, 2010), p.38.

70. Koopmans and Erbe, 'Towards a European Public Sphere? Vertical and Horizontal Dimensions of Europeanized Political Communication', p.101.

71. Ibid.

72. M. Brüggemann and K. Kleinen-von Königslöw, 'Let's Talk About Europe: Why Europeanization Shows a Different Face in Different Newspapers?', European Journal of Communication, Vol.24, No.1 (2009), p.34.

73. In October 2004, trust in the television, radio and written press was 57, 51, 47 per cent respectively. In May 2005, this ratio was 59, 56, 55 per cent respectively. See European Commission, European Commission Standard Eurobarometer Survey on Turkish Cypriot Community No. 62, 64, 2004-05a, available from http://ec. europa.eu/COMMFrontOffice/publicopinion/index.cfm/Survey/index\#p=1\&instruments=STANDARD.

74. Canan Onurer, 'News Director of Kıbrıs Postası Newspaper and Kıbrıs Postası Online News, Former President of the Turkish Cypriot Press Workers Union' (Face-to-Face Interview, translated into English from Turkish, conducted in Kıbris Postası Newspaper Headquarters, Nicosia, Cyprus, on 28 December 2017). Kıbris Postası was founded as a privately-owned online news portal in 2001 and, from 2012, continues both in print and online. The newspaper does not have a relationship with any political party.

75. In disseminating information about the European Union, Kıbrıs Postası newspaper devotes 90 per cent of its space to news related to the EU and associated with Cyprus. 10 per cent of the news related with Europe is about developments in the European Union institutions and other member states non-related to the Cyprus issue (ibid.).

76. Cenk Mutluyakalı, 'Chief Editor of Yenidüzen Newspaper'.

77. Canan Onurer, 'News Director of Kıbrıs Postası Newspaper and Kıbrıs Postası Online News, Former President of the Turkish Cypriot Press Workers Union'.

78. European Commission, European Commission Standard Eurobarometer Survey on Turkish Cypriot Community No. 63-68, 2005-07, available from http://ec.europa.eu/COMMFrontOffice/publicopinion/index.cfm/Survey/index\# $\mathrm{p}=1$ \&instruments $=$ STANDARD.

79. European Commission, European Commission Standard Eurobarometer Survey on Turkish Cypriot Community No. 63-71, 2005-09, available from http://ec.europa.eu/COMMFrontOffice/publicopinion/index.cfm/Survey/index\# $\mathrm{p}=1$ \&instruments $=$ STANDARD.

80. European Commission, European Commission Standard Eurobarometer Survey on Turkish Cypriot Community No. 63-76, 2005-11, available from http://ec.europa.eu/COMMFrontOffice/publicopinion/index.cfm/Survey/index\# $\mathrm{p}=1$ \&instruments=STANDARD.

81. Canan Onurer, 'News Director of Kıbrıs Postası Newspaper and Kıbrıs Postası Online News, Former President of the Turkish Cypriot Press Workers Union'.

82. Cenk Mutluyakalı, 'Chief Editor of Yenidüzen Newspaper'.

83. Sami Özuslu, 'Chief Editor of Sim TV and Sim Radio, President of the Turkish Cypriot Journalists Association', Canan Onurer, 'News Director of Kıbrıs Postası Newspaper and Kıbrıs Postası Online News, Former President of the Turkish Cypriot Press Workers Union', Başaran Düzgün, 'Chief Editor of Havadis Newspaper and Radio Havadis' stated that Turkish Cypriot news media considers the 'European issues as part of the foreign news' and does not employ staff to closely follow the European Union issues.

84. Canan Onurer, 'News Director of Kıbrıs Postası Newspaper and Kıbrıs Postası Online News, Former President of the Turkish Cypriot Press Workers Union'.

85. Y. Katsourides, 'Negative Images of Europe in an Era of Crisis: The Media and Public Opinion in Cyprus', Journal of Contemporary European Studies, Vol.24, No.1 (2016), p.67.

86. Sami Özuslu, 'Chief Editor of Sim TV and Sim Radio, President of the Turkish Cypriot Journalists Association'.

87. Ibid.

88. Canan Onurer, 'News Director of Kıbrıs Postası Newspaper and Kıbrıs Postası Online News, Former President of the Turkish Cypriot Press Workers Union'.

89. European Commission, European Commission Standard Eurobarometer Survey on Turkish Cypriot Community No. 67-87, 2007-2017, available from http://ec.europa.eu/COMMFrontOffice/publicopinion/index.cfm/Survey/ index\# $\mathrm{p}=1$ \&instruments $=$ STANDARD .

90. European Commission, European Commission Standard Eurobarometer Survey on Turkish Cypriot Community No. 82-87, 2014-17, available from http://ec.europa.eu/COMMFrontOffice/publicopinion/index.cfm/Survey/index\# $\mathrm{p}=1$ \&instruments $=$ STANDARD . 